\title{
Lethal familial protracted diarrhoea
}

\author{
D C A CANDY, V F LARCHER, D J S CAMERON, A P NORMAN, J H TRIPP, \\ P J MILLA, J R PINCOTT, AND J T HARRIES
}

The Hospital for Sick Children, and Institute of Child Health, London

SUMMARY 24 children with severe protracted diarrhoea from 10 families, in which at least one sibling was affected, are reported. In two families the siblings were from 1st-cousin marriages, in one family both parents had unaffected children from previous marriages, and in another family the mother had a normal daughter from an earlier marriage. The onset of the diarrhoea was on the first day of life in 12 infants, some time during the first 17 days in 10, and at 13 weeks and 1 year 6 days in the remaining two. In each case the diarrhoea was 'cholera-like'. Investigations failed to show any of the established causes of protracted diarrhoea and $21(87.5 \%)$ infants died after an illness that had lasted between 12 days and 6 years 38 weeks, despite periods of prolonged intravenous feeding and the administration of a wide variety of pharmacological agents. The 2 patients who recovered appeared to do so spontaneously. $14(58 \%)$ had associated extra-gastrointestinal or gastrointestinal-related anomalies. Steady-state perfusion studies were performed in the proximal jejunum of 2 patients, and in the colon of one. In both cases the jejunum was in a net secretory state with respect to water, glucose absorption was markedly reduced, and the transmural potential difference was also depressed; in one of these patients fructose absorption was also reduced, and in the other colonic function appeared to be normal. These studies suggest that the diarrhoea resulted from small intestinal secretion overwhelming the reabsorptive capacity of a normally-functioning colon. Although this series of lethal protracted diarrhoea does not represent a single disease entity, the familial pattern suggests an autosomal recessive mode of inheritance for at least one of the conditions.

We have previously reported a series of 82 cases of protracted diarrhoea in infancy and briefly described 6 patients in whom diarrhoea dated from the newborn period; ${ }^{1}$ of these 6 patients, 2 were siblings and 2 others had similarly affected siblings. Four of the 6 patients died, giving a mortality rate for the series of $5 \%$.

We now report 24 cases (including the 4 patients we described earlier), from 10 families in which at least one sibling also had severe protracted diarrhoea. Each patient has presented to one of three hospitals* during the last 14 years, and 22 of them have been reported in abstract form. ${ }^{2}$

\section{Patients}

The clinical details of the patients and unaffected siblings are shown in Table 1. The siblings in families 2 and 7 were from 1st-cousin marriages, both

*The Hospital for Sick Children, Great Ormond Street, London; King's College Hospital, London; and the Royal Children's Hospital, Melbourne, Australia. parents of the siblings in family 6 had unaffected children from previous marriages, and the mother of the siblings in family 5 had a normal daughter from a previous marriage. Cases $3,6,10,11,13$, and 14 were born by breech delivery, Case 24 by caesarean section; birth was normal in the remainder.

Mean birthweight was $3.03(2.32$ to 3.97$) \mathrm{kg}$, age at referral to one of the three hospitals was 12 weeks ( 1 day to 1 year 15 weeks) weighing 3.19 $(1 \cdot 8$ to $6 \cdot 1) \mathrm{kg}$, and mean age at death or discharge was 1 year 1 week ( 12 days to 6 years 38 weeks) when they weighed $4.54(2 \cdot 0$ to $10 \cdot 25) \mathrm{kg}$.

The onset of the diarrhoea was on the first day of life in 12 infants, some time during the first 17 days in 10 , and at 13 weeks and 1 year 6 days in the remaining 2 patients. The condition of Cases 8 and 9 improved spontaneously at 23 and 26 weeks and, at the time of writing, Case 18 is alive but still has protracted diarrhoea. Protracted diarrhoea persisted until death in 21 patients, resulting in a mortality rate of $87.5 \%$. 
16 Candy, Larcher, Cameron, Norman, Tripp, Milla, Pincott, and Harries

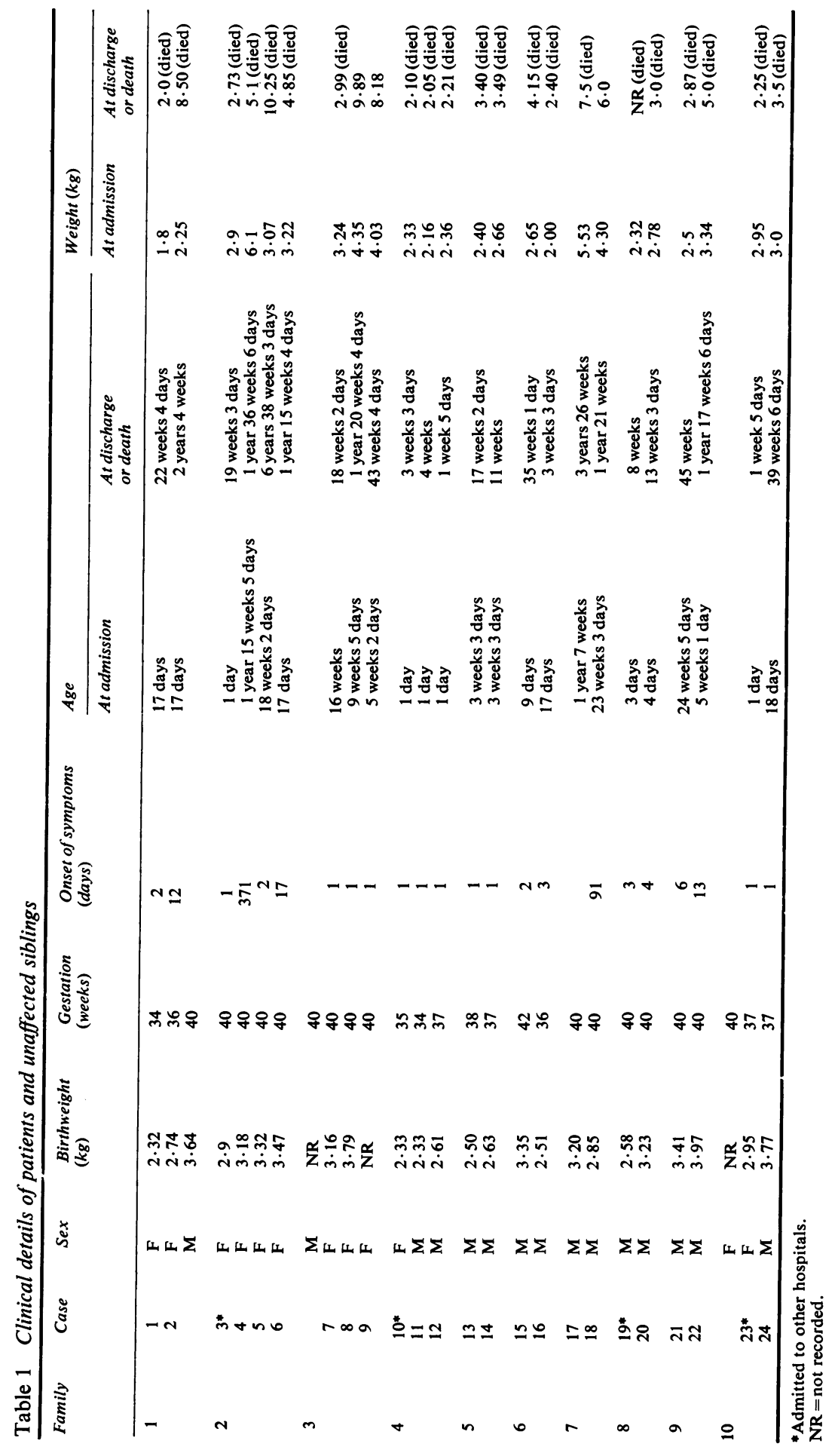




\section{Investigations}

Investigations were performed for diagnostic purposes and to study the possible pathophysiological mechanisms of the diarrhoea. No clear diagnosis could be established in any of them. A number of abnormal investigations (for example, anaemia, thrombocytopenia, electrolyte disturbances, hypoproteinaemia) were considered to be secondary to the primary underlying disease.

Investigations which were relevant to the gastrointestinal tract are given below.

Duodenal intubation. Pancreatic enzyme activities (trypsin, lipase, amylase) were normal in 9 patients (Cases 2, 5, 8, 15, 17, 18, 21, 22, and 24). Four patients had bacterial overgrowth (that is, $>10^{5}$ organisms $/ \mathrm{ml}$ ), and the species were Klebsiella, Escherichia coli, enterococci, Clostridium perfringens, and anaerobic streptococci; eradication with oral antibiotics failed to reduce stool volume.

Small intestinal biopsy. 18 peroral jejunal biopsies were performed in $\mathbf{8}$ patients and the results of these studies are shown in Table $2 .^{3-4}$

The morphological appearances under light microscopical examination varied from normal to subtotal villous atrophy in the group as a whole, but it varied too in patients in whom more than one biopsy was performed. The severity of the enteropathy did not correlate with the severity of the diarrhoea; for example, 24-hour stool volumes were greatest in Case 2 in whom biopsy appearances were either normal or showed partial villous atrophy.

Of particular interest was Case 24, whose biopsy showed an hypoplastic villous atrophy with megaloblastic crypt cell nuclei, paucity of Paneth cells, and a predominantly histiocytic infiltration of the lamina propria. In view of the results of the rectal biopsy and barium enema (see below), and the pronounced rhythmic activity with no response to rectal dilatation on ano-rectal manometry, an ileostomy was performed (on the basis of a possible abnormality of large-bowel innervation, for example (adynamic bowel'). Ileal biopsy at operation also showed hypoplastic villous atrophy. This appearance is typical of that seen in vitamin B12 deficiency states $^{5}$ and was associated with a very low serum B12 concentration (40 ng/l, normal range 160-950) at 16 weeks, a macrocytic anaemia, megaloblastic bone marrow, thrombocytopenia, and normal serum transcobalamin (TC) I and II levels. ${ }^{6}$ TC I concentration was 350 (range 72-1057) $\mathrm{ng} / \mathrm{l}$, and TC II 1435 (range 650-1891) ng/l. ${ }^{7}$

The electron microscopical appearances in Case 2 were essentially normal (Figure) apart from a

Table 2 Studies on small intestinal biopsies

\begin{tabular}{|c|c|c|c|c|c|c|c|c|c|}
\hline \multirow[t]{2}{*}{ Case } & \multirow{2}{*}{$\begin{array}{l}\text { Age } \\
\text { (weeks) }\end{array}$} & \multirow[t]{2}{*}{ Histology } & \multirow[t]{2}{*}{ Lactase* $^{*}$} & \multirow[t]{2}{*}{ Sucrase } & \multirow[t]{2}{*}{ Isomaltase } & \multirow[t]{2}{*}{ Maltase } & \multirow[t]{2}{*}{$\left(\mathrm{Na}^{+}-\mathrm{K}^{+}\right)-A T P a s e \ddagger$} & \multicolumn{2}{|c|}{ Adenylate cyclase $\dagger$} \\
\hline & & & & & & & & Basal & $\begin{array}{l}\text { Fluoride- } \\
\text { stimulated }\end{array}$ \\
\hline 1 & 18 & Normal & & & & & & & \\
\hline 2 & $\begin{array}{r}75 \\
97 \\
103\end{array}$ & $\begin{array}{l}\text { PVA } \\
\text { Normal } \\
\text { Normal }\end{array}$ & & & & & $0 \cdot 92$ & $6 \cdot 9$ & $66 \cdot 8$ \\
\hline 11 & 3 & Normal & & & & & & & \\
\hline 18 & $\begin{array}{l}24 \\
43\end{array}$ & $\begin{array}{l}\text { PVA } \\
\text { SPVA }\end{array}$ & $1 \cdot 7$ & $2 \cdot 6$ & $0 \cdot 7$ & 0.9 & & & \\
\hline 20 & $\begin{array}{r}4 \\
8 \\
12\end{array}$ & $\begin{array}{l}\text { STVA } \\
\text { PVA } \\
\text { SPVA }\end{array}$ & $\begin{array}{l}0.9 \\
1.4\end{array}$ & $\begin{array}{l}2 \cdot 2 \\
1 \cdot 4\end{array}$ & & $\begin{array}{l}8 \cdot 6 \\
3 \cdot 4\end{array}$ & & & \\
\hline 21 & 40 & STVA & 0.4 & $0 \cdot 2$ & & $1 \cdot 3$ & & & \\
\hline 22 & $\begin{array}{r}5 \\
8 \\
10 \\
11 \\
26 \\
46\end{array}$ & $\begin{array}{l}\text { SPVA } \\
\text { PVA } \\
\text { PVA } \\
\text { PVA } \\
\text { PVA } \\
\text { PVA }\end{array}$ & $\begin{array}{l}1 \cdot 6 \\
4 \cdot 3 \\
3 \cdot 0 \\
3 \cdot 4 \\
3 \cdot 4\end{array}$ & $\begin{array}{l}2 \cdot 0 \\
4 \cdot 0 \\
3 \cdot 2 \\
2 \cdot 1 \\
3 \cdot 5\end{array}$ & & $\begin{array}{r}6 \cdot 8 \\
15 \cdot 9 \\
\\
9 \cdot 9 \\
8 \cdot 3 \\
13 \cdot 5\end{array}$ & & & \\
\hline 24 & $\begin{array}{r}5 \\
18\end{array}$ & $\begin{array}{l}\text { HVA §§ } \\
\text { HVA }\end{array}$ & & & & & $\begin{array}{l}0.60 \\
0.94\end{array}$ & $\begin{array}{r}7 \cdot 2 \\
10 \cdot 1\end{array}$ & $\begin{array}{l}127 \\
175\end{array}$ \\
\hline
\end{tabular}

PVA = partial villous atrophy, SPVA = severe partial villous atrophy, STVA = subtotal villous atrophy, HVA=hypoplastic villous atrophy.

*Disaccharidases assayed by method of Plotkin and Isselbacher $;^{3}$ results expressed as units/g wet weight of mucosa; normal values for lactase, sucrase, isomal tase, and maltase $>2 \cdot 5,3 \cdot 0,1 \cdot 0$, and $10 \cdot 0$ respectively.

¥Assayed by the method of Tripp et al.;4 results expressed as $\mu \mathrm{mol}$ inorganic phosphate/mg protein per 60 minutes; normal range $1.38-4.58$. †Assayed by the method of Tripp et al.;4 results expressed as pmol cyclic-AMP/mg protein/10 minutes; normal basal range 7.28-18.24; normal fluoride stimulated range 62.4-209.7.

$\S \S R$ esults for ileal biopsy obtained at surgery. Normal ranges for ileal mucosal enzymes not available. 


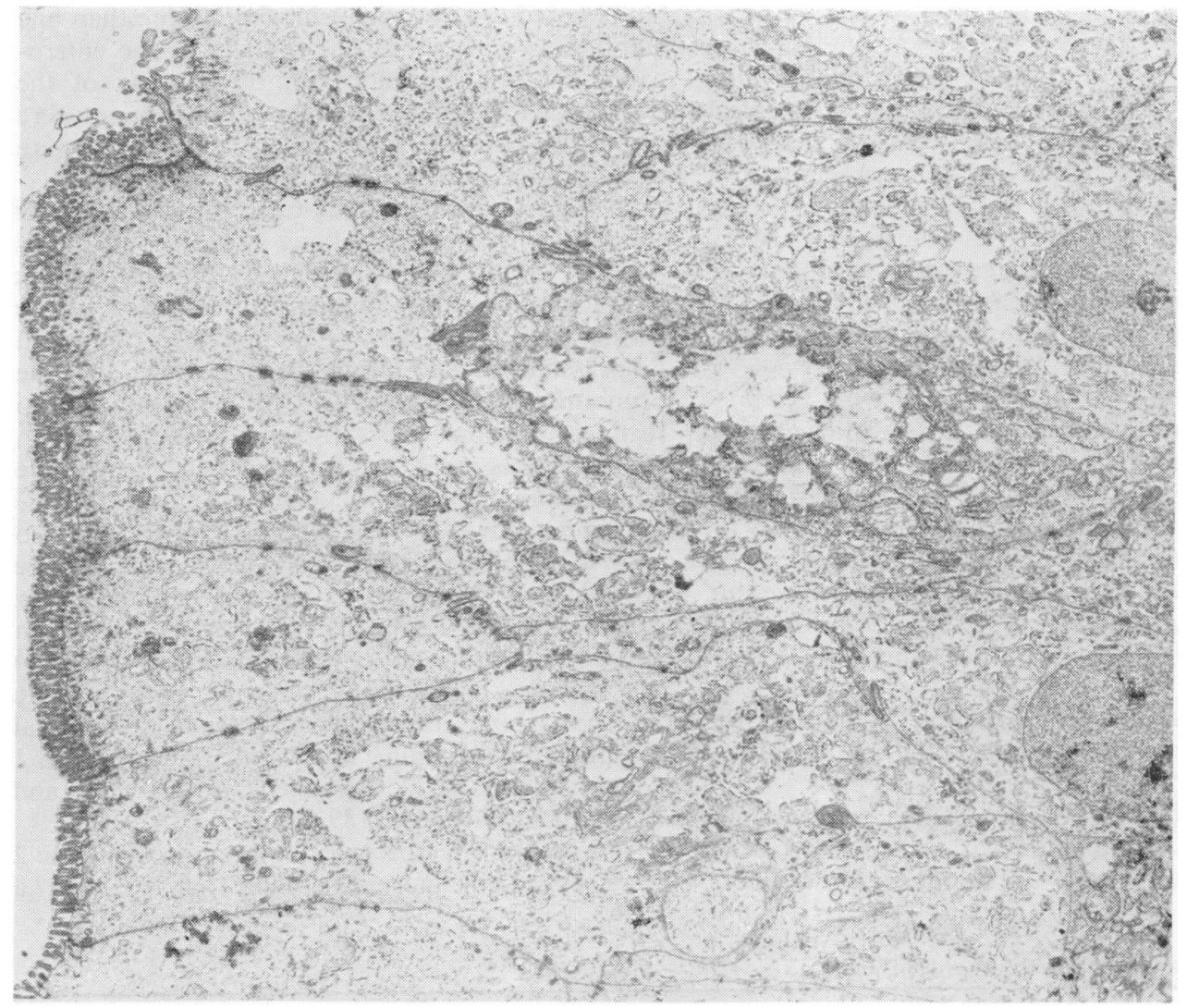

Figure Electron microscopical examination of jejunal biopsy. Enterocytes (from junction of middle and upper third of villus) have shorter and broader microvilli compared with normal; structural appearances of subcellular organelles appear normal. $\times 9800$.

slight degree of microvillous shortening. Immunocytochemical studies $^{8}$ on this biopsy, using antibodies against gastrin, secretin, motilin, gastric inhibitory peptide, cholecystokinin, bombesin, vasoactive intestinal peptide, substance $P$, glucagon, pancreatic polypeptide, enkephalin, and neurotensin were normal.

Rectal biopsy. Rectal biopsies were performed in 10 patients (Cases 1, 4, 7, 9, 15, 17, 20, 21, 22, and 24) and were normal under light microscopical examination in Cases 7, 9, 15, and 17; in the remainder there was a mild mixed inflammatory infiltrate in the lamina propria, eosinophils being particularly prominent in Cases 1 and 20. Ganglion cells were decreased but present in Case 24 .

Barium studies. Barium meal and follow-through examinations showed small hiatus herniae in 5 patients (Cases 2, 9, 20, 21, and 22), nonspecific malabsorptive changes in 3 (Cases 4,5 , and 17), and were entirely normal in 5 patients (Cases $1,7,8,15$, and 19). In Case 1, barium enema showed slight, nonobstructive narrowing of the sigmoid colon and was normal in Cases 2, 4, 5, 7, 18, and 21 .

Sweat test. Pilocarpine iontophoresis yielded sweat sodium concentrations of $8-46 \mathrm{mmol} / \mathrm{l}$ (normal $<70$ ) in Cases 1, 2, 4, 5, 6, 8, 15, 17, 20, 21, 22, and 24.

Stool electrolytes. Stool electrolytes were determined in 10 patients (Cases 1, 2, 5, 6, 12, 17, 20, 21, 22, and 24). Stool chloride ranged from 20 to $93 \mathrm{mmol} / \mathrm{l}$ but at no time exceeded the sum concentrations of sodium and potassium.

None of the 24 patients had any features to suggest a diagnosis of congenital chloridorrhoea except, of course, the profuse watery diarrhoea. 
Plasma copper and zinc. Copper and zinc concentrations in plasma were determined in 7 patients (Cases 2, 16, 17, 20, 21, 22, and 24) and 2 patients (Cases 17 and 21) had low copper concentrations of $5.34 \mu \mathrm{mol} / \mathrm{l}(34 \mu \mathrm{g} / 100 \mathrm{ml})$ and $3.2 \mu \mathrm{mol} / 1(20$ $\mu \mathrm{g} / 100 \mathrm{ml}$ ) respectively (normal range $12 \cdot 6-26 \cdot 8$ $\mu \mathrm{mol} / \mathrm{l}(80-170 \mu \mathrm{g} / 100 \mathrm{ml})$. Plasma copper concentration fell to $0.94 \mu \mathrm{mol} / \mathrm{l}(6.0 \mu \mathrm{g} / 100 \mathrm{ml})$ in Case 17 and he was given intravenous copper EDTA. Zinc concentrations were normal when first measured but the concentration in Case 21 fell to $3.1 \mu \mathrm{mol} / \mathrm{l}(206 \cdot 6 \mu \mathrm{g} / \mathrm{l})$ (normal range 9.2-29.1 $\mu \mathrm{mol} / 1 ; 610 \cdot 3-1940 \cdot 0 \mu \mathrm{g} / \mathrm{l})$ during the course of his illness. Parenteral zinc supplements resulted in disappearance of the ectodermal manifestations of zinc deficiency (peri-oral and perineal rash, paronychia, and alopecia) but the diarrhoea continued.

Hormones. Serum vasoactive intestinal peptide, calcitonin, and gastrin were determined by radioimmunoassay $^{8}$ in 6 patients (Cases 2, 18, 20, 21, 22, and 24). Concentrations were normal except for gastrin in Cases 2 and 24 which were slightly raised at 55 and 80 pmol/1 respectively (normal $<50$ ).

Immunological studies. Serum immunoglobulins were determined in 15 patients (Cases 1, 2, 4-6, 8, $9,15-18,20-22$, and 24) and were normal or raised in 10 (Cases 9, 15-22, and 24). Two sisters (Cases 4 and 6) had low IgG and Case 5 had low IgA, while two sisters (Cases 1 and 2) had low IgG and IgM concentrations. In view of the low IgM level it seems likely that a primary immunodeficiency state (rather than excessive gut loss of immunoglobulin) occurred in these sisters.

Yeast opsonisation ${ }^{9}$ was determined in sera from 4 patients (Cases 2, 16, 18, and 24) and was defective in Case 18 (opsonisation index 1.12 compared with control value of $4 \cdot 64$ ).

Intestinal perfusion studies. The absorption of monosaccharides and water was measured in the proximal jejunum of Cases 2 and 24 using a double-lumen steady-state technique with simultaneous monitoring of the transmural potential difference (PD) as previously described, ${ }^{10}$ and in Case 24 colonic absorption of water and electrolytes was also measured.

Solutions 2, 3, and 4 (Table 3) contained polyethylene glycol $4000(3 \mathrm{~g} / \mathrm{l})$ as a nonabsorbable marker, sodium bicarbonate $\left(\mathrm{NaHCO}_{3}\right) 25 \mathrm{mmol} / \mathrm{l}$, potassium chloride $(\mathrm{KCl}) 4 \mathrm{mmol} / \mathrm{l}$, and osmolality was adjusted to $285-290 \mathrm{mmol} / \mathrm{kg}$ by the addition of sodium chloride $(\mathrm{NaCl})$ and $\mathrm{pH}$ adjusted to $7 \cdot 0$ by gassing with $\mathrm{CO}_{2}$. In Cases 2 and 24 solution 1 was physiological saline. Solution 2 contained

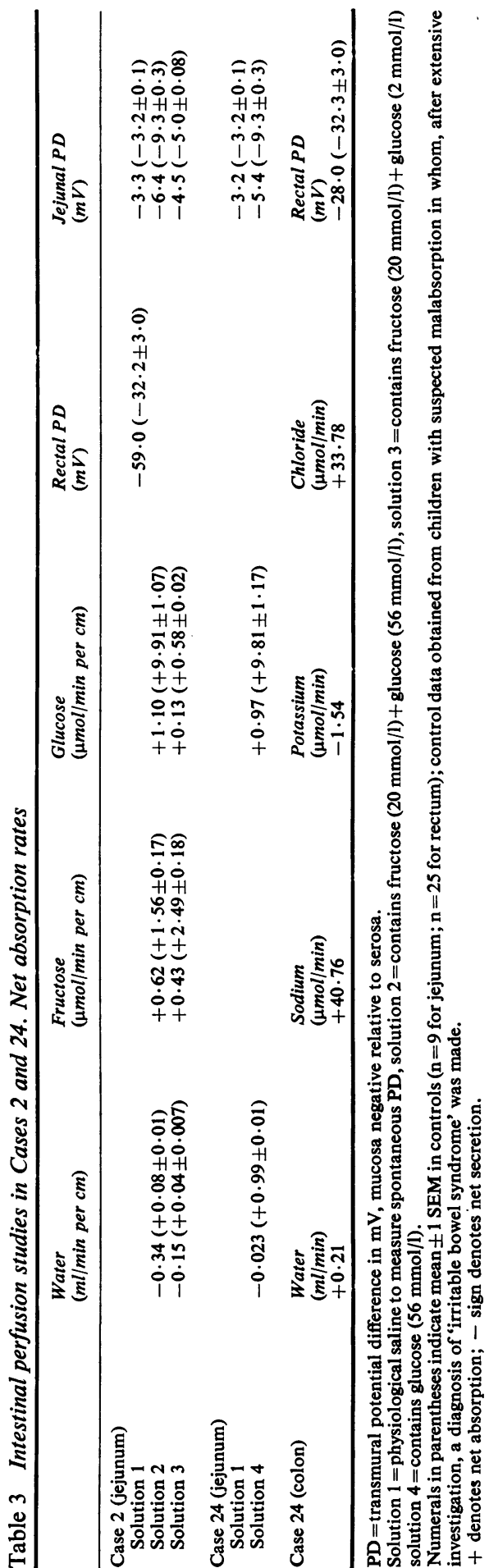


fructose $(20 \mathrm{mmol} / \mathrm{l})$ and glucose $(56 \mathrm{mmol} / \mathrm{l})$, solution 3 fructose $(20 \mathrm{mmol} / \mathrm{l})$ and glucose $(2$ $\mathrm{mmol} / \mathrm{l})$, and solution 4 glucose alone $(56 \mathrm{mmol} / \mathrm{l})$. In Case 24 the entire colon was perfused with an isotonic solution containing $\mathrm{NaCl}(100 \mathrm{mmol} / \mathrm{l})$, $\mathrm{KCl}(6 \mathrm{mmol} / \mathrm{l}), \mathrm{NaHCO}_{3}(40 \mathrm{mmol} / \mathrm{l})$, and polyethylene glycol $(5 \mathrm{~g} / \mathrm{l})$ at $\mathrm{pH} 7.0$ using the defunctioning limb of the ileostomy and placing an 8 FG Foley catheter in the rectum. Samples were analysed for polyethylene glycol, fructose, and glucose ${ }^{11-13}$ sodium and potassium were measured by flame photometry, and chloride by coulometric titration. Net rates of absorption or secretion of water and solutes were calculated according to standard formulae ${ }^{14}$ and results are expressed as the mean of three 10-minute collections.

In both cases the jejunum was in a net secretory state with respect to water, glucose absorption was greatly reduced and, in Case 2, fructose absorption was also reduced although to a lesser extent than glucose (Table 3). Glucose-evoked PD was also depressed in both patients. In Case 2 rectal PD was raised. In Case 24 the colon appeared to function normally, water, $\mathrm{Na}^{+}$and $\mathrm{Cl}^{-}$being absorbed, and $\mathrm{K}^{+}$being secreted with a normal PD.

Necropsy findings. Necropsy was performed in 17 patients and the abnormal findings are shown in Table 4. These findings did not add to the investigations which were performed during life in defining the primary cause of the diarrhoea.

Associated anomalies. $14(58 \cdot 3 \%)$ had extragastrointestinal or gastrointestinal-related abnormalities. The extra-gastrointestinal anomalies included absence of the organ of Corti (Case 4), premature fusion of skull sutures (Case 12), a bifid terminal phalanx of the left index finger (Case 5), dysplasia of right kidney (Case 2), and right hydronephrosis (Case 15), absence of the corpus callosum, hypotonia, low-set ears, dislocated hips and knees, and malformation of the lower cervical vertebrae (Cases 13 and 14). One patient (Case 24) had episodes of skin desquamation which occurred regularly at intervals of 2 to 3 weeks.

The most common gastrointestinal-related abnormality was hiatus hernia (Cases 2, 9, 20-22). Other abnormalities were inguinal herniae (rightsided in Case 17, bilateral in Case 22), pancreatic acinar dilatation (Case 24), intra-abdominal adhesions and universal mesentery (Case 7), and generalised speckled areas of intra-abdominal calcification (Case 2), slight narrowing of the sigmoid colon (Case 1), and a Meckel's diverticulum (Case 1).
Table 4 Necropsy findings

\begin{tabular}{|c|c|c|}
\hline Family & Case & \\
\hline 1 & 2 & $\begin{array}{l}\text { Fatty infiltration of liver. Dilated small bowel. } \\
\text { Shortened villous cores }\end{array}$ \\
\hline 2 & 3 & $\begin{array}{l}\text { Small adrenals with cortical atrophy. Fatty in- } \\
\text { filtration of the liver. Gastrointestinal tract } \\
\text { otherwise normal } \\
\text { Absent organ of Corti }\end{array}$ \\
\hline 3 & 7 & $\begin{array}{l}\text { Ascending colon, transverse colon, and small- } \\
\text { intestine on universal mesentery. Gastrointestinal } \\
\text { tract otherwise normal }\end{array}$ \\
\hline 4 & $\begin{array}{l}10 \\
11\end{array}$ & $\begin{array}{l}\text { Bronchopneumonia. Gastrointestinal tract normal } \\
\text { Fatty infiltration of liver. Mild periportal fibrosis. } \\
\text { Gastrointestinal tract otherwise normal }\end{array}$ \\
\hline & 12 & $\begin{array}{l}\text { Premature fusion of all sutures. Intraventricular } \\
\text { haemorrhage. Gastrointestinal tract normal }\end{array}$ \\
\hline 5 & 13 & $\begin{array}{l}\text { Agenesis of corpus callosum. Undescended testes. } \\
\text { Gastrointestinal tract normal }\end{array}$ \\
\hline & 14 & $\begin{array}{l}\text { Agenesis of corpus callosum, agyria. Hypostatic } \\
\text { pneumonia. Undescended testes. Fatty infiltration } \\
\text { of liver. Gastrointestinal tract otherwise normal }\end{array}$ \\
\hline 6 & 15 & $\begin{array}{l}\text { Sagittal sinus thrombosis. Innominate vein throm- } \\
\text { bosis. Bronchopneumonia. Right pyohydro- } \\
\text { nephrosis. Gastrointestinal tract otherwise normal }\end{array}$ \\
\hline & 16 & $\begin{array}{l}\text { Sagittal sinus thrombosis. Fatty infiltration of liver. } \\
\text { Gross congestion, exudation, and linear focal } \\
\text { ulceration of entire colon. Small-bowel less } \\
\text { affected }\end{array}$ \\
\hline 8 & $\begin{array}{l}19 \\
20\end{array}$ & $\begin{array}{l}\text { Gastrointestinal tract normal (limited necropsy) } \\
\text { Patent ductus arteriosus, grossly fatty liver. Villi } \\
\text { absent throughout entire small-bowel }\end{array}$ \\
\hline 9 & 21 & $\begin{array}{l}\text { Dense peritoneal adhesions. Large- and small-bowel } \\
\text { inflammation resembling necrotising enterocolitis. } \\
\text { Patchy liver fibrosis }\end{array}$ \\
\hline & 22 & $\begin{array}{l}\text { Large- and small-bowel inflammation with shortened } \\
\text { villi and dense lymphocytic and plasma cell } \\
\text { infiltrate of the lamina propria. Extensive myo- } \\
\text { cardial degeneration and fibrosis }\end{array}$ \\
\hline 10 & 23 & $\begin{array}{l}\text { Cerebral oedema. Bilateral otitis media. Renal vein } \\
\text { thrombosis }\end{array}$ \\
\hline & 24 & $\begin{array}{l}\text { Dense peritoneal adhesions. Dilatation of the small } \\
\text { bowel and colon to splenic flexure. Shortened } \\
\text { villous cores (in duodenum and ileum). Pan- } \\
\text { creatic acinar dilatation }\end{array}$ \\
\hline
\end{tabular}

\section{Course}

Except for two sisters (Cases 5 and 6) the severe watery diarrhoea was persistent, and 11 of the 21 patients who died were below their birthweights at death, after an illness lasting between 12 days and 6 years 38 weeks (Table 1 ).

The 2 patients (Cases 8 and 9) who recovered appeared to do so spontaneously. In all cases the diarrhoea was 'cholera-like'. An extreme example was Case 2 in whom the 24-hour stool volume, when she was 22 -months old and weighed $8.2 \mathrm{~kg}$, was $6900 \mathrm{ml}$.

\section{Management and complications}

Dietary exclusion of disaccharides, monosaccharides, cows' milk, soya protein, or gluten had no effect on the diarrhoea. Intravenous feeding was used in 12 
patients (Cases, 1, 2, 11, 12, 15, 16, 19-24) for periods ranging from 7 days to 50 weeks; in 10 of them stool character and volume remained unchanged despite the fact that they received nothing by mouth. Adrenocorticoids were administered to 11 patients (Cases 2, 5, 6, 10, 11, 15, 16, 20, 22-24) and were effective in Cases 5 and 6 . These 2 patients were sisters from a 1st-cousin marriage (family 2 ) in which all 4 siblings died. Prednisolone $(2 \mathrm{mg} / \mathrm{kg}$ a day) greatly reduced stool volume but reduction of the dose below $1 \mathrm{mg} / \mathrm{kg}$ a day resulted in relapse. The prolonged treatment with high dosage steroids necessary to control the diarrhoea led to severe side effects-such as moon facies, telangiectasia, pathological fractures, cataracts, and muscle wasting. All 4 siblings developed anaphylactic reactions to repeated challenges with a variety of dietary proteins, particularly milk and rice.

In addition to steroids, a variety of other drugs such as oral broad-spectrum antibiotics, disodium cromoglycate, prostaglandin synthetase inhibitors (for example, indomethacin, sulphasalazine), betablockers, antihistamines, cholestyramine, and nonspecific anti-diarrhoeal agents failed to reduce the diarrhoea and did not arrest the progressive deterioration in the condition of the patients. The infant (Case 24) with vitamin B12 deficiency did not respond to high dose parenteral B12. Immunoglobulin injections were without benefit in Case 2 (who had low IgG and IgM). Weekly plasma infusions (17 in all) were given to Case 18 who had defective yeast opsonisation and although the defect was corrected by the infusions there was no reduction in the diarrhoea.

As might be expected, numerous complications related to the disease process or to therapy occurred in the patients. All the previously described complications ${ }^{15-16}$ occurred at some stage in the patients treated with intravenous feeding. Case 2 developed a Horner's syndrome caused by bleeding and extravasation of blood from a cutdown incision for placement of an intravenous catheter into the right internal jugular vein; the same patient had a perforation of the inferior vena cava by an indwelling catheter which resulted in a temporary ileus which spontaneously resolved; hypocalcaemic laryngospasm and tetany complicated her illness too.

\section{Discussion}

In this paper we report a highly lethal form of familial protracted diarrhoea in 24 patients from 10 families, of whom 20 presented to three hospitals during a period of 14 years. The series consisted of 13 boys and 11 girls and in three sibships there were unaffected siblings; 3 of the parents had unaffected children from previous marriages and there were 2 1st-cousin marriages. This familial pattern suggests a genetic basis for the diarrhoea, inheritance being probably by an autosomal recessive mode, although there may be more than one recessive condition present. A study of the familial pattern of idiopathic' protracted diarrhoea is currently in preparation in which the genetics will be discussed at length. Greene et al. ${ }^{17}$ described 2 patients who had siblings with self-limiting diarrhoea in early life, and 3 of the patients reported by Lloyd-Still et al. ${ }^{18}$ had a family history of chronic inflammatory bowel disease, but none of these patients was a sibling. Necrotising enterocolitis has been reported in 3 of 4 children from the same family who died in early infancy and an autosomal mode of inheritance was suggested. ${ }^{19}$ None of our patients had an illness resembling necrotising enterocolitis, except perhaps as a terminal event in Cases 16 and 21. Davidson $e t$ $a .^{20}$ described 5 infants with severe protracted diarrhoea from birth, 4 of whom died; 3 had siblings who died, and 2 were products of consangineous marriages.

None of the established genetically-determined causes of protracted diarrhoea appeared to be operating, and our patients probably represent an heterogenous group with respect to the primary cause of the diarrhoea. There were many features in common: all but 2 of the patients presented within the first 3 weeks of life, the course was relentlessly downhill in the 21 children who died, 11 were below their birthweights at death, and there was a high incidence of extra-gastrointestinal and gastrointestinal-related anomalies. The association of certain anomalies with protracted diarrhoeal states in childhood has been reported by others. ${ }^{18}{ }^{21-22}$

Cases 13 and 14 showed many of the features of the Smith-Lemli-Opitz syndrome ${ }^{23}$ including scaphocephaly, low-set ears, retroussé nose, medial epicanthus, broad alveolar ridges, small palpebral fissures, hip dislocation, clenched hands, sacral dimple, cryptorchidism, convulsions, and mental retardation. To our knowledge however, the association of absence of the corpus callosum and severe protracted diarrhoea has not been reported.

Except for Cases 5 and 6 who responded to steroids, a variety of dietary manipulations and drugs failed to reduce the diarrhoea and the 2 patients who recovered appeared to do so spontaneously. Of the 12 patients who received intravenous feeding, 10 continued to have profuse diarrhoea despite receiving nothing by mouth, as was the case in the patients reported by Davidson et al. ${ }^{20}$

The jejunal and ileal biopsies from Case 24 showed megaloblastic changes and these, together 
with the other findings in this patient, suggested a primary abnormality of B12 metabolism, possibly one of membrane transport or cellular utilisation. It is tempting to speculate that a causal relationship existed between such an abnormality and the diarrhoea. Jejunal biopsies in the 5 patients reported by Davidson et al. ${ }^{20}$ showed hypoplastic villous atrophy too, but, in contrast to our patient, there was no evidence of any haematological defect.

The mild nonspecific changes found in the rectal biopsies of 6 patients were presumed to be secondary to the diarrhoea. ${ }^{24-25}$

Perfusion studies were performed in Cases 2 and 24 in an attempt to define the pathophysiological mechanism operating in the genesis of their diarrhoea. In both patients the proximal jejunum was in a net secretory state with respect to water, fructose and glucose absorption was impaired from varying intraluminal concentrations, and $P D$ was reduced. Although no control data are available to compare with the results of colonic perfusion in Case 24, the data are compatible with a normal functioning colon-that is water, sodium, and chloride were absorbed, potassium was secreted into the lumen, and rectal PD was normal; rectal PD was increased in Case 1.

These observations suggest that in these 2 patients the diarrhoea resulted from small intestinal secretion of fluid and electrolytes overwhelming the reabsorptive capacity of a normal colon, as occurs in patients with cholera. ${ }^{26}$ The mechanisms underlying small intestinal secretion have been under intense investigation in recent years and there is now evidence that the 2 mucosal enzymes, adenylate cyclase and $\left(\mathrm{Na}^{+}-\mathrm{K}^{+}\right)$-ATPase are fundamental in the regulation of fluid and solute transport across the small intestine, and in the pathogenesis of various diarrhoeal states. ${ }^{27-28}$ Adenylate cyclase participates in secretion of water and electrolytes, whereas $\left(\mathrm{Na}^{+}-\mathrm{K}^{+}\right)$-ATPase is concerned with active sodiumcoupled absorption of monosaccharides and aminoacids which creates osmotic gradients for passive water absorption. Since adenylate cyclase and $\left(\mathrm{Na}^{+}-\mathrm{K}^{+}\right)$-ATPase regulate opposing transport systems, increased activity of the former or reduced activity of the latter will result in a net secretory state.

Certain bacterial toxins, vasoactive intestinal peptide hormone, and prostaglandins activate adenylate cyclase and induce small intestinal secretion; gastrin and calcitonin also stimulate secretion of water and electrolytes. ${ }^{29}\left(\mathrm{Na}^{+}-\mathrm{K}^{+}\right)-$ ATPase activity is reduced in viral diarrhoea ${ }^{30}$ and in active coeliac disease there is a paradoxical reduction in $\left(\mathrm{Na}^{+}-\mathrm{K}^{+}\right)$-ATPase activity with an increase in adenylate cyclase activity which may reflect an increased population of immature surface epithelial cells in this condition. ${ }^{4}$ In both Cases 2 and $24\left(\mathrm{Na}^{+}-\mathrm{K}^{+}\right)$-ATPase was greatly reduced, whereas adenylate cyclase activity was normal. This finding could account for the secretion of water, malabsorption of glucose, and reduced jejunal PD in these 2 patients and may have been contributory in the pathogenesis of the diarrhoea, but is probably not the sole explanation for the profuse diarrhoea. Serum vasoactive intestinal peptide hormone and calcitonin levels were normal and gastrin levels were only slightly raised. Although prostaglandins were not assayed, the failure of large doses of prostaglandin synthetase inhibitors to influence stool volume mitigates against a role for prostaglandins in the pathogenesis of the diarrhoea. Although we have clearly demonstrated that the jejunum was in a net secretory state and that $\left(\mathrm{Na}^{+}-\mathrm{K}^{+}\right)-\mathrm{ATPase}$ activity was reduced in these 2 patients, other as yet undefined mechanisms were presumably in operation.

Protracted diarrhoeal states in children, particularly in young infants, present major problems in diagnosis and management and the underlying pathophysiological mechanisms in many such patients are poorly understood. ${ }^{1}$ Fordtran, ${ }^{31}$ in a review on the pathogenesis of diarrhoea, concluded by drawing attention to lethal protracted diarrhoea in young infants and proposed that such patients had undefined congenital defects of some kind and represented an important area for further work. Our series of patients supports his proposition and stresses the continuing challenge which these patients present with respect to the pathophysiological mechanisms responsible for their diarrhoea. Moreover, studies directed towards such patients may throw light on the pathogenesis of other diarrhoeal states.

\section{Addendum}

Since completing this paper we have observed a further family of three siblings, 2 of whom have developed severe protracted diarrhoea. The first sibling, a girl, died at 2 months 2 weeks from diarrhoea dating from birth. Her brother developed diarrhoea from 12 days which has persisted, and at 1 year 9 months he remains dependent on intravenous feeding; the results of small intestinal perfusion studies were essentially similar to those of Cases 2 and 24. A 7-year-old brother is well.

We thank the referring consultants for permission to publish details of their patients, Dr N Sourial from Professor D L Mollin's Department of 
Haematology, St Bartholomew's Hospital, for the TC I and TC II assays, Dr Brian Lake, The Hospital for Sick Children, for the electron micrographs, and Dr J M Polak and Dr S R Bloom, Royal Postgraduate Medical School, Hammersmith Hospital, for the immunocytochemical studies and hormone assays.

D C A C received financial support from the Rayne Foundation.

\section{References}

1 Larcher V F, Shepherd R, Francis D E M, Harries J T. Protracted diarrhoea in infancy. Analysis of 82 cases with particular reference to diagnosis and management. Arch Dis Child 1977; 52: 597-605.

2 Candy D C A, Larcher V F, Cameron D J S, Norman A P, Harries J T. Lethal familial protracted diarrhoea of undetermined cause: a report of 22 cases (abstract). Gut 1977; 18: A989-90.

3 Plotkin G R, Isselbacher K J. Secondary disaccharidase deficiency in adult celiac disease (non-tropical sprue) and other malabsorption states. $N$ Engl J Med 1964; 271: 1033-7.

4 Tripp J H, Manning J A, Muller D P R, et al. Mucosal adenylate cyclase and sodium-potassium stimulated adenosine triphosphatase in jejunal biopsies of adults and children with coeliac disease. In: McCarthy C F, Fottrell P F, eds. Perspectives in coeliac disease. Lancaster: MTP Press, 1978: 461-70.

5 Foroozan P, Trier J S. Mucosa of the small intestine in pernicious anemia. $N$ Engl J Med 1967; 277: 553-9.

6 Hom B L, Ahluwali B K. The vitamin B12 binding capacity of transcobalamin I and II of normal human serum. Scand J Haematol 1968; 5: 64-8.

7 Hom B, Oleson H. Molecular weights of vitamin B12 binding proteins in human serum determined by Sephadex G-200 gel filtration. Scand J Clin Lab Invest 1967; 19: 269-73.

8 Pearse A G E, Polak J M, Bloom S R. The newer gut hormones. Cellular sources, physiology, pathology, and clinical aspects. Gastroenterology 1977; 72: 746-61.

9 Soothill J F, Harvey B A M. Defective opsonisation. A common immunity deficiency. Arch Dis Child 1976; 51: 91-9.

10 Milla $P$ J, Atherton D A, Lake B D, Leonard J V, Wolff $\mathbf{O} \mathbf{H}$. Disordered intestinal function in glycogen storage disease. J Inborn Errors Metab 1980; 1 : 155-7.

11 Roe J H, Epstein H T, Goldstein N P. A photometric method for the determination of insulin in plasma and urine. J Biol Chem 1949; 178: 839-45.

12 Hyden S. A turbidimetric method for the determination of higher polyethylene glycols in biological materials. Kungligen Lantbrukshogskol Annaler 1955; 22: 139-45.

13 Werner W, Rey H G, Wielinger M. Uber die Eigenschaften eines neuen Chromogens fur die Blutzuckerbestimmung nach. GOD/POD Method. $Z$ Analyt Chem 1970; 252: 224-31.
14 Sladen G E, Dawson A M. Interrelationships between the absorptions of glucose, sodium, and water by the normal human jejunum. Clin Sci 1969; 36: 119-32.

15 Harries J T. Parenteral feeding-complications (abstract). Arch Dis Child 1974; 49: 824.

16 Harries J T. Aspects of intravenous feeding in childhood. In: Johnston I D A, ed. Advances in parenteral nutrition. Lancaster: MTP Press, 1978: 267-80.

17 Greene H L, McCabe D R, Merenstein G B. Protracted diarrhea and malnutrition in infancy: changes in intestinal morphology and disaccharidase activities during treatment with total intravenous nutrition or oral elemental diets. $J$ Pediatr 1975; 87: 695-704.

18 Lloyd-Still J D, Shwachman H, Filler R M. Protracted diarrhea of infancy treated by intravenous alimentation. I. Clinical studies of 16 infants. Am J Dis Child 1973; 125: 358-64.

19 Fried K, Vure E. A lethal autosomal recessive enterocolitis of early infancy. Clin Genet $1974 ; 6$ : 195-6.

20 Davidson G P, Cutz E, Hamilton J R, Gall D G. Familial enteropathy: a syndrome of protracted diarrhea from birth, failure to thrive, and hypoplastic villus atrophy. Gastroenterology 1978; 75: 783-90.

21 Avery G B, Villavicencio O, Lilly J R, Randolph J G. Intractable diarrhea in early infancy. Pediatrics 1968; 41: 712-22.

22 Sherman J O, Hamly C-A, Khachadurian A K. Use of an oral elemental diet in infants with severe intractable diarrhea. J Pediatr 1975; 86: 518-23.

${ }^{23}$ Smith D W, Lemli L, Opitz J M. A newly recognized syndrome of multiple congenital anomalies. J Pediatr $1964 ; 64: 210-7$.

24 Morson B C, Dawson I M P. Inflammatory disorders. In: Gastrointestinal pathology. Oxford: Blackwell, 1972: 448-92.

25 Dickinson R J, Gilmour H M, McClelland D B L. Rectal biopsy in patients presenting to an infectious disease unit with diarrhoeal disease. Gut $1979 ; 20$ : 141-8.

26 Banwell J G, Scherr H. Effect of bacterial enterotoxins on the gastrointestinal tract. Gastroenterology 1973; 65: 467-97.

27 Field M. Intestinal secretion. Gastroenterology 1974; 66: 1063-84.

28 Schultz S G, Frizzell R A, Nellans H N. Ion transport by mammalian small intestine. Annu Rev Physiol 1974; 36: 51-91.

29 Hendrix T R, Paulk H T. Intestinal secretion. In: Crane $\mathrm{R}$ K, ed. Gastrointestinal physiology II. International Review of Physiology. Vol. 12. Baltimore: University Park Press, 1977:257-84.

30 Davidson G P, Gall D G, Petric M, Butler D G, Hamilton J R. Human rotavirus enteritis induced in conventional piglets. J Clin Invest 1977; 60: 1402-9.

31 Fordtran J S. Speculations on the pathogenesis of diarrhea. Fed Proc 1967; 26: 1405-14.

Correspondence to $\mathrm{Dr} \mathrm{J} \mathrm{T}$ Harries, Institute of Child Health, 30 Guilford Street, London WC1N $1 \mathrm{EH}$.

Received 13 November 1979 